\title{
Does Diversification Strategy Reduce The Level of Financial Distress? (Evidence from Indonesia)
}

\author{
Yeterina Widi Nugrahanti ${ }^{1,2}$, Sutrisno $\mathrm{T}^{1}$, Aulia Fuad Rahman ${ }^{1}$, and Endang Mardiati ${ }^{1}$ \\ ${ }^{1}$ Faculty of Economics and Business University of Brawijaya, Indonesia \\ ${ }^{2}$ Economics and Business Faculty Satya Wacana Christian University, Indonesia \\ ${ }^{1}$ yeterina.nugrahanti@staff.uksw.edu
}

\begin{abstract}
The objective of this study is to investigate the effect of diversification strategy towards the level of financial distress. Altman Z-score is used to measure the level of financial distress and Herfindahl index is used to measure diversification in this research. This study used 101 non-financial companies listed in Indonesian Stock Exchange during 2014-2016 (303 firm years) as samples. For testing the hypotheses, Mann Whitney test and panel data regression with random effect model was used. The results showed that there are $\mathrm{Z}$ score differences between high and low diversified firms; and diversification has a negative effect towards the level of financial distress. The control variables testing showed that liquidity, profitability, and firm size negatively influence the level of financial distress, while leverage has a positive effect towards the level of financial distress. Besides, the type of diversification has no effect toward financial distress.
\end{abstract}

Keywords: diversification, financial distress, altman z-score, herfindahl index

\section{Introduction}

The issues of financial distress are getting more attention in the last 20 years as the increasing number of big companies that went bankrupt [1]. Go public companies that faced financial distress and cannot improve their performances, will be delisted from the stock market [2]. Based on IDX fact book data, from 2009 to 2017, Indonesian Stock Exchange has forced delisted the trading of 27 companies because the companies were facing financial distress. Financial distress which is not overcome immediately will lead to bankruptcy and liquidation [3], therefore the managers have to set a strategy to avoid financial distress.

One of the strategies that can be applied in order to avoid and reduce the level of financial distress is diversification. Diversification happens when a company runs more than one business or industry [4]. Referring to the Resource Based View Theory, diversification is an important strategy to create competitive advantage and to survive in the business competition [5], [6]. Diversification will result in efficiency, synergy, and better risk management in the owned business segments [7], [8] ; allow expansion of products and new markets [7], [8], as well as increasing the debt capacity [9], [10]. Those benefits of diversification will avoid the company from financial distress [11]-[13].

Many of the previous studies about diversification focus on the effect of diversification toward financial performance (profitability) [14]-[17]. The weakness of financial performance measurement is only focused on the shareholders wealth [4]. The funding resource of a company is obtained not only from the shareholders, but also from the creditors. A company which has good performance and high profit does not guarantee that it can pay its obligation, when the 
profit does not turn into cash. Financial distress not only cover a company's ability to generate profit and return to shareholders, but also represent a company's ability to pay their obligation. Therefore, a study about the influence of diversification on financial distress is important to be carried out.

Studies about the effect of diversification on financial distress are rarely conducted. In a condition of industry distress, a company which is diversified will be spared from financial constraint [18]. Diversification reduced the probability of bankruptcy in America [12]. The product diversifications have negative impact on the bankruptcy risk in Vietnam [19].

This study aims to investigate the effect of diversification on the financial distress level in Indonesian companies. Diversification will give different impact in every company's financial condition in many countries. This condition is caused by the differences in institutional and economic environment which happens in the related countries [20]. Referring to economic condition in Indonesia during 2012-2017 which is categorized as developing country [21] and tend to face financial distress [22], so the diversification effect testing toward financial distress in Indonesia is important to be carried out. This study contributes to accounting literature in several aspects. First, this study tests the role of diversification in reducing financial distress which rarely done. This study is the first study in Indonesia which specifically discusses the effect of diversification on financial distress. Second, related to the financial distress measurement, this study does not classify companies into two groups (companies that are bankrupt and companies that are not bankrupt) as conducted by the previous researchers [12]. The Altman $\mathrm{Z}$ score is applied in this study in order to reflect the financial distress level more precisely [23], [24].

The rest of this paper is organized as follows. Section 2 presents a literature review and hypothesis. Section 3 describes the research method. Section 4 discusses the empirical results. Section 5 offers our conclusions.

\section{Literature Review and Hypothesis}

\subsection{Financial Distress}

Corporate financial distress is a rather vague term, which can be further attributed to four generic terms commonly used in business research: failure, insolvency, bankruptcy and default [1]. Failure happens when a company's revenue is not sufficient to cover its expense and when the level of investment return is lower compared to its capital cost. Insolvency happens when a company is unable to pay its short term obligation because the company is less liquid, and when the total debt is higher than the fair value of total assets. A company default occurs when the debtor breaks the debt covenants. Bankruptcy happens when a company is legally stated as pailit and has to be liquidated. Financial distress is a stage of decline in financial conditions which happens before bankruptcy or liquidation[3].

\subsection{Diversification}

According to the Resource Based Theory, diversification is one of company strategies to reach competitive advantage [7], [25]. Referring to the stakeholder theory, diversification will implicate to the increasing number and types of stakeholder, so diversified companies will interact and it is possible to gain more benefit from the stakeholders compared to non-diversified companies [6]. Diversification happens when a company enters a new industry [26]; a new business segment [5] , or runs more than one business [4]. Diversification is differentiated into product diversification and geographic diversification [12], [27]. Product diversification consists of related and unrelated diversification. Related diversification is when a company produces new product/service which is related to the existing products in the company. 
Unrelated diversification is when a company adds a new product/ service which is not related to the existing products in the company. Meanwhile, geographic diversification is divided into national diversification and international diversification.

\subsection{Diversification and Financial Distress}

According to the stakeholder theory, the success of a company operational is influenced by its stakeholders. Diversification applied by a company will be followed by the increasing number and types of stakeholders. The diversified companies will interact and it is possible to gain more benefit from their stakeholders compared to the non-diversified companies [6]. The benefit gained can be the increasing of market which the company gets from customers, the increasing of economic scale and efficiency which are gained from the employees, as well as the increasing of debt capacity which is gained from the creditors. Those benefits gained by diversified companies from their stakeholders will help the company in reducing financial distress.

The influence of diversification on financial distress will be also explained using the resource based view theory. Based on the resource based view theory, diversification is a strategy to gain competitive advantage and to enable resource transfer inter-sections in a company [25], [28]. Diversification will improve performance as it enables the company to access skills, resources, assets or competency that cannot be bought or acquired by the nondiversified companies in a competitive market [7].

Diversification will give benefit for the company, and the benefit acquired is expected to be able to reduce financial distress. The resources sharing and skills transfer in a diversified company will result in a synergy which can reduce the operational expense and/or it can produce different products [7], [8]. A diversified company will operate in another geographic area and creates varied products, so it will increase the market power. This market power will stabilize the company position and the company can apply predatory pricing to increase its profit [5], [29]. Diversification will also increase the company's debt capacity [9], [10]. The increasing profit as the effect of the synergy and market power, and the increasing debt capacity which is acquired from diversification will reduce financial distress [12], [13], [25].

Diversification will also give benefit of tax saving and help the company to gain optimized leverage level [11]. In addition, it is easier for a diversified company to get funding from the stock market (Stein, 1997). The tax saving benefit and the ease in getting funding will also reduce company's financial distress. The diversification is proven to has negative influence on the tendency of bankruptcy and liquidation [12], [19]. From the previous explanation, a hypothesis is proposed:

H1: There are differences in the level of financial distress between high and low diversified firms.

H2: Diversification has negative effect on financial distress.

\section{Research Method}

\subsection{Data and Samples}

The samples used in this study were non-financial companies registered in Indonesian Stock Exchange (ISE) during 2014-2016. The sampling method used in this study was purposive sampling, and the criteria are: (1) the annual report closing date is on December $31^{\text {st }}$, (2) the companies did not carry out any merger and acquisitions, (3) the financial report is recorded in Rupiah currency, and (4) the data are available. This study is a preliminary research and We only use 101 firms (303 observations) as samples. The diversification data, the financial ratio to 
calculate financial distress, and the control variable were acquired from the annual report downloaded from www.idx.co.id.

\subsection{Research Variables}

\subsubsection{Financial Distress (The Dependent Variable)}

Financial distress is measured using Altman Z Score. The higher the Z score indicates the lower level of financial distress in a company [23], [24], [31].

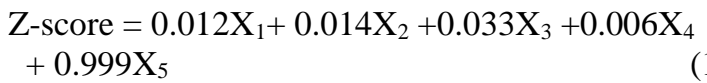

X1 : Working Capital to Total Assets

X2 : Retained Earnings to Total Assets

X3 : Earning before interest and taxes to Total Assets

X4 : Market value of Equity to Book Value of Debt

X5 : Sales to Total Assets

$\mathrm{Z}$ : Overall Index

\subsubsection{Diversification (The Independent Variable)}

Diversification used in this study includes product and geographic diversification [12], [32], and measured using the Herfindahl Index [32]-[35]. The Herfindahl Index can be calculated as follow:

$$
\mathrm{H}=1-\sum_{i=1}^{n} P i^{2}
$$

Pi: the sales on segment $i$ is divided by the total sales in the company

$\mathrm{n}$ : the number of segments in a company

$\mathrm{H}$ : Overall Index

The Herfindahl Indeks number ranges between 0 and 1; if the number is getting closer to 1 , it means that the company is getting more diversified [27], [33], [35].

\subsubsection{The Control Variable}

The control variables in this study were the company size (log total market capitalization), liquidity (current assets/ current liabilities), profitability (ROA=net income/ total assets), and leverage (DER=total debt/ total equity) [24], [36], [37]. The type of diversification (product and geographic diversification) were also used as the control variable. The type of diversification measurement would use variable dummy $(0=$ product diversification; $1=$ geographic diversification).

\subsection{Compare Mean Test and Regression Model}

Compare mean test (Independent sample t test/ Mann Whitney test) using SPSS was used for testing the first hypothesis (H1). The panel data regression using Eviews 10 was applied in second hypothesis $(\mathrm{H} 2)$ testing. Empirical model that was applied in order to test $\mathrm{H} 2$ is provided as follow:

Z-SCORE $=\alpha+\beta_{1}$ HERFINDAHL $+\beta_{2}$ SIZE $+\beta_{3}$ LIQUIDITY $+\beta_{4}$ ROA $+\beta_{5}$ DER $+\beta_{6}$ TYPE 


\section{Result and Discussion}

\subsection{Descriptive Statistic}

Based on the purposive sampling, this study used 101 non financial companies registered in the ISE during 2014-2016 (303 observations). The descriptive statistics variable that consist of mean, minimum, maximum and standard deviation is displayed in the Table 1 below:

Table 1. Descriptive Statistics (pooled sample $=303$ )

\begin{tabular}{|l|l|l|l|l|}
\hline \multicolumn{1}{|c|}{ Variable } & Mean & \multicolumn{1}{|c|}{ Min } & \multicolumn{1}{|c|}{ Max } & $\begin{array}{c}\text { Std. } \\
\text { Dev }\end{array}$ \\
\hline Z score & 1.759 & -0.968 & 32.598 & 4.039 \\
\hline Herfindahl & 0.312 & 0.000 & 0.995 & 0.250 \\
\hline Firm Size & 12.285 & 10.178 & 14.649 & 0.939 \\
\hline Liquidity & 4.642 & 0.0005 & 42.342 & 16.989 \\
\hline ROA & 0.098 & -0.426 & 0.432 & 0.089 \\
\hline DER & 0.407 & -8.204 & 9.175 & 1.047 \\
\hline
\end{tabular}

From 303 observations, there are 52 observations (17.16\%) do not apply diversification and there are 251 observations $(82.84 \%)$ are proven applying diversification. Out of 251 observations that apply diversification, there are 191 observations $(76.1 \%)$ applied product diversification and 60 observations $(23.9 \%)$ applied geographic diversification. Most of the samples (83\%) are proven facing financial distress as their Z score is below 1.8 [23].

\subsection{Hypotheses Testing Results}

\subsubsection{H1 Testing Result}

Compare mean test using Mann-Whitney and the T-Test aims to determine whether there are differences in the level of financial distress based on diversification, liquidity, profitability, leverage, firm size and type of diversification. The grouping of diversification, liquidity, profitability, leverage, and firm size in two groups (high/big and low/small) is based on the average of each variable. Table 2 shows the result of these tests:

Table 2. Compare Mean Test Result

\begin{tabular}{|c|c|c|c|}
\hline Variable & Group (N) & $\begin{array}{c}\mathrm{Z} \\
\text { score } \\
\text { mean } \\
\end{array}$ & $P$ value \\
\hline Herfindahl & High (152) & 2.093 & \multirow[t]{2}{*}{$0.004 * * *$} \\
\hline & Low (151) & 1.423 & \\
\hline Liquidity & High (48) & 4.381 & \multirow[t]{2}{*}{$0.076^{*}$} \\
\hline & Low (255) & 1.286 & \\
\hline ROA & High (83) & 3.096 & \multirow[t]{2}{*}{$0.000 * * *$} \\
\hline & Low (220) & 1.259 & \\
\hline \multirow[t]{2}{*}{ DER } & High (111) & 0.884 & $0.000 * * *$ \\
\hline & Low (192) & 2.270 & \multirow{3}{*}{$0.080^{*}$} \\
\hline Firm Size & Big (176) & 2.081 & \\
\hline & Small (127) & 1.329 & \\
\hline \multirow{2}{*}{$\begin{array}{l}\text { Type of } \\
\text { Diversification }\end{array}$} & Product (191) & 1.851 & \multirow[t]{2}{*}{0.385} \\
\hline & $\begin{array}{l}\text { Geographic } \\
(60)\end{array}$ & 1.695 & \\
\hline
\end{tabular}

Notes: * significant on alpha $10 \%$ 


$$
\begin{aligned}
& * * \text { significant on alpha } 5 \% \\
& * * * \text { significant on alpha } 1 \%
\end{aligned}
$$

The compare mean test result shows that there are $\mathrm{Z}$ score differences between high and low diversified companies, therefore $\mathrm{H} 1$ is accepted. $\mathrm{Z}$ score in high diversified firms is higher than $\mathrm{Z}$ score in low diversified fims, so the level of financial distress in high diversified firms is lower than the level of financial distress in low diversified firms. Besides, the compare mean test result also showed that there are $\mathrm{Z}$ score differences based on the high/big and low/small of liquidity, profitability, leverage, firm size; and no $\mathrm{Z}$ score differences based on the type of diversification (product diversification and geographic diversification).

\subsubsection{H2 Testing Result}

The hypothesis two testing result using panel data regression $(n=303)$ with random effect model is provided in table 3 .

Table 3: Regression Result

\begin{tabular}{|l|l|l|l|}
\hline \multicolumn{1}{|c|}{ Variable } & \multicolumn{1}{c|}{$\beta$} & \multicolumn{1}{c|}{$\mathrm{t}$-Stat } & Conclusion \\
\hline Intercept & -1.922 & -4.913 & - \\
\hline Herfindahl & 0.194 & $2.292^{* *}$ & $\begin{array}{l}\mathrm{H} 2 \\
\text { accepted }\end{array}$ \\
\hline Liquidity & 0.052 & $6.283^{* * *}$ & $\begin{array}{l}\text { negative } \\
\text { effect }\end{array}$ \\
\hline ROA & 1.095 & $5.534 * * *$ & $\begin{array}{l}\text { negative } \\
\text { effect }\end{array}$ \\
\hline DER & -0.031 & $-2.155^{* *}$ & $\begin{array}{l}\text { positive } \\
\text { effect }\end{array}$ \\
\hline Firm Size & 0.138 & $4.377^{* * *}$ & $\begin{array}{l}\text { negative } \\
\text { effect }\end{array}$ \\
\hline $\begin{array}{l}\text { Types of } \\
\text { diversification }\end{array}$ & -0.029 & -0.361 & no effect \\
\hline
\end{tabular}

Dependent variable Z score

R squared $\quad 0.251$

Adjusted R square $\quad 0.234$

F-statistic $15.240 * * *$

Notes: * significant on alpha $10 \%$

** significant on alpha $5 \%$

$* * *$ significant on alpha $1 \%$

Financial distress was the dependent variable in this study, which is measured using Altman $\mathrm{Z}$ score. The higher the $\mathrm{Z}$ score acquired, the lower the level of financial distress in a company [23], [24], [31]. The hypothesis testing result shows that the diversification coefficient was positive and significant, so it means that the higher the level of diversification, the higher the $\mathrm{Z}$ scores, so the lower the financial distress. Therefore, $\mathrm{H} 2$ is accepted and it can be concluded that diversification has negative influence on the level of financial distress.

\subsubsection{Discussion}

The hypotheses testing results proved that (a) there is $\mathrm{Z}$ score difference between high and low diversified firms, and (b) diversification negatively influence the level of financial distress. 
The result of this study is in line with the result of study conducted by [12], [19]who concluded that diversification had negative impact on the tendency of bankruptcy and liquidation.

The result of this study is in agreement with the stakeholder theory, which believes that a diversified firms will gain more benefit from its stakeholders compared to non-diversified firms [6]. It also supports the resource-based view theory which believes that diversification is a strategy to reach competitive advantage and allow resources transfer inter-sections in a company [25], [28].

[12], [13] explained coinsurance effect of diversification. Diversification will reduce the level of financial distress when there is an imperfect correlation between segments' cash flow. When one segment has cash shortage, this shortage can be filled by the other segments that have cash overage. It allows a company to run the business normally and pay its obligation on the due date, so this condition will reduce the possibility and the level of financial distress in the company.

Product diversification which is conducted by a company will increase the sales by means of the creation of various new products, which will improve its market power and win in a competitive market [29]. The sales improvement can be realized into cash, which later can reduce the level of financial distress. A company which applies geographic diversification will also gain benefit. The benefit gained is from the low service cost and the optimal utilization of intangible assets, such as the marketing ability, production skill, and customer satisfaction [19]. Geographic diversification will increase company value and reduce financial distress through global manufacture and flexible production shift ability [38]. In addition, by operating in different geographic area, a company can reduce sales volatility and the risk of bankruptcy.

Diversification will improve performance, which includes reducing financial distress, when the diversification can create synergy and economic scale for the company. Economic scale occurs when investment mix applied by the company can result in cost saving or higher income. Synergy can be produced from skill sharing and resources transfer, which in the end creates cost advantage [7], [8], [39]. Sharing activity will enable managers of a diversified company to have a unique skill, which can be used to expand the multi-business strategy, increase performance, and reduce financial distress in a company [40].

Diversification also enables a company to increase its debt capacity [9], [10]; gain benefit from tax saving and help the company to get the optimal level of leverage [11] also ease the company in getting funding in the stock market [30]Those benefits will help the company in avoiding and reducing financial distress. As examples of the study data, a company which has high diversification value also has high Z score. In 2015, PT. Enseval Putera Mega Trading's diversification level was 0.99 , and its $Z$ score was 2.94 ; in 2014, PT. Kalbe Farma's diversification score was 0.74 , and its $\mathrm{Z}$ score was 3.15 ( $\mathrm{Z}$ score above 1.8 means that a company does not face financial distress). On the other hand, a company which has low diversification level is proven to have low Z score. In 2014, PT. Achasti Pharma's diversification value was 0.004, and its Z score was 0.97 ; in 2015, PT. AKR Corporindo's diversification value was 0.03, and its $\mathrm{Z}$ score was 1.01 (if the $\mathrm{Z}$ score was below 0.81 , it indicates financial distress in a company). Therefore, it can be concluded that the higher the diversification, the higher the $\mathrm{Z}$ score, and the lower the financial distress of a company.

\subsection{The Effect of Liquidity, Profitability, Leverage, Firm Size and Type of Diversification on The Level of Financial Distress}

The regression result shows that liquidity negatively influence financial distress. The higher the liquidity level, the more current assets availability in order to cover companies' short term debt [24], [36]. Profitability is proven to have negative effect to financial distress. A company 
that have high profitability will be more trusted by investors and creditors as their investment target [41]. The ease in obtaining fund will decrease the level of financial distress [24], [42], [43]. Leverage positively affect financial distress. The higher the leverage ratio is, the higher the business risk and default risk that cause financial distress [24].

Firm size is proven to have negative effect on financial distress. Big firms have many assets that can be converted into cash and are more trusted by the creditors when they look for loans in order to overcome financial distress [24], [42]. The type of diversification have no effect toward financial distress. Both product and geographic diversification will help a company to avoid and reduce financial distress [39]. Product diversification will increase the sales by creating various new products and eficiency in buying the capital resources for production. Meanwhile, geographic diversification allows a company to reach markets in different area and has an area which has low cost resources. The benefit of product and geographic diversification will reduce financial distress in a company.

\subsection{Robustness Test}

For improving the robustness of findings, this study conducted tests using another diversification proxy, which is number of segments [12], [35]; and other financial distress measurements, which are the Altman revision model (Z' score) and Altman modification model (Z' score). The Altman revision model can be applied to go public and non go public companies. The Altman modification model eliminated variable X5 in Altman classic model (Z score) because this ratio is different in the industry with different assets' size. The higher the score obtained in the Altman revision and modification model, the lower the financial distress level in a company. The robustness test results which are regression coefficient, $t$ statistic (written in parentheses), and significance from each independent variable are is showed in table 4 and table 5.

Table 4. Robustness Test Result

\begin{tabular}{|l|l|l|l|l|}
\hline \multicolumn{1}{|c|}{ Variable } & \multicolumn{1}{|c|}{ Z score } & & Z'score & Z'score \\
\hline Herfindahl & 0.194 & & 0.05 & -0.026 \\
& $(2.29)^{* *}$ & & $(0.449)$ & $(-0.22)$ \\
\hline Liquidity & 0.005 & & 0.05 & 0.007 \\
& $(6.28)^{* * *}$ & & $(5.71)^{* * *}$ & $(5.79)^{* * *}$ \\
\hline ROA & 1.094 & & -0.036 & -0.049 \\
& $(5.53)^{* * *}$ & & $(-1.18)$ & $(-1.57)$ \\
\hline DER & -0.03 & & -0.07 & -0.064 \\
& $(-2.15)^{* *}$ & & $(-4.65)^{* * *}$ & $(-0.86)^{* * *}$ \\
\hline Firm size & 0.138 & & 0.046 & -0.05 \\
& $(4.38)^{* * *}$ & & $(1.18)$ & $(1.339)$ \\
\hline Type of & -0.027 & & -0.222 & -0.284 \\
diversification & $(-0.36)$ & & $(-1.913)^{*}$ & $(-2.508)^{* *}$ \\
\hline
\end{tabular}

Z' score $=0,717$ (working capital/total asset $)+0,847$ (retained earnings/total asset $)+3,108($ EBIT/total asset $)+0,42$ (book value of equity/ book value of total debt) $+0,988$ (sales/ total asset)

Z" score $=3,25$ (working capital/ total asset) $+6,56$ (retained earnings / total asset $)+6,72($ EBIT/ total asset $)+1,05$ (book value of equity/book value of total debt) 


\begin{tabular}{|l|l|l|l|}
\hline \multicolumn{1}{|c|}{ Variable } & \multicolumn{1}{c|}{ Z score } & Z'score & Z'score \\
\hline Number of & -0.023 & 0.262 & 0.320 \\
segments & $(-0.163)$ & $(1.78)^{*}$ & $(1.81)^{*}$ \\
\hline Liquidity & 0.005 & 0.011 & 0.006 \\
& $(6.13)^{* * *}$ & $(5.92)^{* * * *}$ & $(5.67)^{* * *}$ \\
\hline ROA & 1.14 & -0.03 & -0.047 \\
& $(5.72)^{* * *}$ & $(-0.588)$ & $(-1.52)$ \\
\hline DER & -0.03 & -0.194 & -0.06 \\
& $(-2.13)^{* *}$ & $(-5.91)^{* * *}$ & $(-3.79)^{* * *}$ \\
\hline Firm size & 0.139 & 0.09 & 0.059 \\
& $(4.33)^{* * *}$ & $(2.48)^{* *}$ & $(1.51)$ \\
\hline Type of & 0.068 & 0.156 & -0.267 \\
diversification & $(0.63)$ & $(-1.79)^{*}$ & $(-2.36)^{* *}$ \\
\hline
\end{tabular}

The robustness test results show that diversification measured using the number of segments negatively affects financial distress measured using the Altman revision and Altman modification model.

\section{Conclusion}

This study aims to evaluate the effect of diversification on the level of financial distress. Although there are many studies about financial distress, this study gives contribution in assessing the impact of diversification which has rarely been studied so far, especially in Indonesia. The Mann-Whitney test result shows that there are financial distress differences between high and low diversified firms. The assessment using the panel data regression with random effect model shows that diversification has negative influence on the level of financial distress. The testing results of the control variables show that liquidity, profitability, and firm size has negative impact on financial distress, while leverage has positive impact on financial distress. Additionally, the testing result also shows that the type of diversification does not influence the level of financial distress.

Based on those results, this study suggests to the investors or creditors to invest in companies that apply diversification, have high liquidity, have high profitability, have big size, and have low leverage level, so the investors and creditors will be saved from the risk of financial distress. It is also suggested for the managers to apply diversification in order to reduce the risk of financial distress. The limitation of this study is not conduct a separated testing related to the type of diversification. The future studies can classify the type of diversification applied by a company into related and non-related diversification (for product diversification), as well as national and international diversification (for geographic diversification), so they can get a clearer explanation on which kind of diversification that can reduce financial distress.

\section{References}

[1] E. I. Altman and E. Hotchkiss, Corporate Financial Distress and Bankruptcy. 2006.

[2] Q. Tao, Y. Sun, Y. Zhu, and X. Yang, "Political Connections and Government Subsidies: Evidence from Financially Distressed Firms in China," Emerg. Mark. Financ. Trade, vol. 53, no. 8, pp. 1854-1868, 2017.

[3] H. D. Platt and M. B. Platt, "Predicting corporate financial distress: Reflections on choice-based sample bias," J. Econ. Financ., vol. 26, no. 2, pp. 184-199, 2002.

[4] D. Patrisia and S. Dastgir, "Diversification and corporate social performance in manufacturing companies," Eurasian Bus. Rev., vol. 7, no. 1, pp. 121-139, 2017. 
[5] C. A. Montgomery, “Corporate Diversification,” J. Econ. Perspect., vol. 8, no. 3, pp. 163-178, 1994.

[6] J. Kang, "The Relationship Between Corporate Diversification and Corporate Social Performance," Strateg. Manag. J., vol. 34, no. 1, p. 94-109., 2012.

[7] C. C. Markides and P. J. Williamson, "Corporate Diversification and Organizational Structure: a Resource Based View,” Acad. Manag. J., vol. 39, no. 2, pp. 340-367, 1996.

[8] Zhou, "Synergy, Coordination Cost and Diversification Choices," Strateg. Manag. J., vol. 32, no. 1, p. 624 .

[9] G. Lewellen, “A Pure Financial Rationale for Conglomerate Merger," J. Finance, vol. 26, no. 2, 1971.

[10] L. D. Su, “Ownership structure, corporate diversification and capital structure: Evidence from China's publicly listed firms," Manag. Decis., vol. 48, no. 2, pp. 314-339, 2010.

[11] Leland, "Financial Synergies and the Optimal Scope of the Firm: Implications for Mergers, Spin-Offs, and Structured Finance," J. Finance, vol. 62, no. 2, pp. 765-807, 2007.

[12] R. Singhal and Y. E. Zhu, "Bankruptcy Risk, Costs and Corporate Diversification," J. Bank. Financ., vol. 37, no. 5, pp. 1475-1489, 2013.

[13] D. Nußmann, "The Coinsurance Effect of Corporate Diversification," no. 1989, pp. 5$16,2018$.

[14] K. V Lins and H. Servaes, "Emerging markets," Financ. Manag., vol. 31, no. 2, pp. 5$31,2002$.

[15] J. Jung and S. M. Chan-Olmsted, "Impacts of media conglomerates' dual diversification on financial performance,” J. Media Econ., vol. 18, no. 3, pp. 183-202, 2005.

[16] A. Wisnuwardhana and V. Diyanty, "Diversification, Firm Performance and Board of Commissioner Monitoring," Proceding Account. Natl. Symp. XVIII Medan 16-19 Sept. 2015, no. September, 2015.

[17] H. Chang, G. D. Fernando, D. Srinivasan, and A. Tripathy, "A Re-Examination of Diversification and Firm Productivity," Ssrn, vol. 25, no. January, pp. 99-118, 2011.

[18] R. Gopalan and K. Xie, "Conglomerates and industry distress," Rev. Financ. Stud., vol. 24, no. 11, pp. 3642-3687, 2011.

[19] N. M. Ha and T. Hoang, "Diversification and Bankruptcy Risk of Companies Listed on the Vietnamese Stock Market," Int. J. Econ. Perspect., vol. 11, no. 2, pp. 177-185, 2017.

[20] A. Chakrabarti, K. Singh, and I. Mahmood, "Diversification and Performance: Evidence from East Asian Firms,” Strateg. Manag. J., vol. 28, no. 1, p. 101, 2007.

[21] M. Brian, "Business perspectives on emerging markets 2012-2017," 2012.

[22] M. A. Hidayat and W. Meiranto, "Financial Distress Prediction in Indonesian Manufacturing Firms," Diponegoro J. Account., vol. 3, no. 2002, pp. 1-11, 2014.

[23] E. I. Altman, "Financial Ratios, Discriminant Analysis and The Prediction of Corporate Bankruptcy," J. Finance, vol. 23, no. 4, pp. 589-609, 1968.

[24] A. Al-Hadi, B. Chatterjee, A. Yaftian, G. Taylor, and M. Monzur Hasan, "Corporate social responsibility performance, financial distress and firm life cycle: Evidence from Australia," Account. Financ., no. 2012, 2017.

[25] W. P. Wan, R. E. Hoskisson, J. C. Short, and D. W. Yiu, "Resource-based theory and corporate diversification: Accomplishments and opportunities," J. Manage., vol. 37, no. 5, pp. 1335-1368, 2011. 
[26] D. Iacobucci and P. Rosa, "Growth, Diversification, and Business Group Formation in Entrepreneurial Firms," Small Bus. Econ., vol. 25, no. 1, 2005.

[27] M. Doaei, M. B. A. Anuar, and N. I. N. A. Hamid, "Corporate Diversification and Financial Performance: A Review of Literature," Asia J. Financ. Account., vol. 4, no. 2, pp. 56-74, 2012.

[28] J. Barney, "Firm Resources and Sustained Competitive Advantadge," J. Manage., vol. 17, no. 1, pp. 99-120, 1991.

[29] P. R. Mendonça and A. L. Casas, "Diversification as a Sustainable Growth Strategy in the Packaging Market : case study of a Brazilian company," vol. 4, no. 2, pp. 61-81, 2013.

[30] J. C. Stein, "Internal Capital Markets and the Competition for Corporate Resources," J. Finance, vol. 52, no. 1, pp. 111-133, 1997.

[31] E. I. Altman, M. Iwanicz-Drozdowska, E. K. Laitinen, and A. Suvas, "Financial Distress Prediction in an International Context: A Review and Empirical Analysis of Altman's Z-Score Model," J. Int. Financ. Manag. Account., vol. 1, no. 1, pp. 1-41, 2016.

[32] D. Vidyanata, Topowijono, and N. Endang, "The Effect of Diversification and Leverege on Financial Distress," Bus. Adm. J., vol. 32, no. 1, pp. 90-97, 2016.

[33] K. H. Kang, S. Lee, K. Choi, and K. Lee, "Geographical Diversification, Risk and Firm Performance of US Casinos,” Tour. Geogr., vol. 14, no. 1, pp. 117-146, 2012.

[34] İ. Yiğit and Ş. Tür, "Relationship Between Diversification Strategy Applications And Organizational Performance According To Herfindahl Index Criteria," Procedia - Soc. Behav. Sci., vol. 58, pp. 118-127, 2012.

[35] F. Franco, O. Urcan, and F. P. Vasvari, "Corporate Diversification and The Cost of Debt: The Role of Segment Disclosures," Account. Rev., vol. 91, no. 4, pp. 1139-1165, 2016.

[36] F. Elloumi and J.-P. Gueyle, "Financial Distress and Corporate Governance: An Empirical Analysis," Corp. Gov., vol. 1, no. 1, pp. 15-23, 2001.

[37] K. Lajili and D. Zéghal, "Corporate Governance and Bankruptcy Filing Decisions," J. Gen. Manag., vol. 36, no. 2, pp. 3-26, 2010.

[38] B. Kogut and N. Kulatilaka, Operating Flexibility, Global Manufacturing, and the Option Value of a Multinational Network, vol. 9, no. 1. 2010.

[39] J. B. Barney, "Resource-based theories of competitive advantage: A ten-year retrospective on the resource-based view," J. Manage., vol. 27, no. 6, pp. 643-650, 2001.

[40] M. A. Hitt, R. D. Ireland, and R. E. Hoskisson, Strategic Management and Startegic Competitiveness, 9th ed. california USA: South-Western College Pub, 2010.

[41] T. O. Nyamboga, B. N. Omwario, and A. M. Muriuki, "Determinants of Corporate Financial Distress: Case of Non- Financial Firms Listed in the Nairobi Securities Exchange," Res. J. Financ. Account., vol. 5, no. 12, pp. 193-207, 2014.

[42] A. Mecaj, M. Isabel, and G. Bravo, "CSR Actions and Financial Distress : Do Firms Change Their CSR Behavior When Signals of Financial Distress Are Identified ?,” Mod. Econ., vol. 5, no. April, pp. 259-271, 2014.

[43] J. Juniarti, "Good Corporate Governance and Predicting Financial Distress Using Logistic and Probit Regression Model," Account. Financ. J., vol. 15, no. 1, pp. 43-50, 2013. 
